\title{
Stigmaphyllon hispidum (Malpighiaceae), a New Species from Bahia, Brazil
}

\author{
Christiane Anderson \\ University of Michigan Herbarium, North University Building, \\ Ann Arbor, Michigan 48109-1057, U.S.A.
}

ABSTRACT. Stigmaphyllon hispidum, a new species of Malpighiaceae, is described from Bahia, Brazil, where it was collected in a remnant of coastal forest, a vegetation type called Mata Atlântica. Its floral structure and adaxial laminar vesture are most similar to those of $S$. gayanum, an endemic of the region of Rio de Janeiro. The dense axial vesture, composed of simple basifixed hairs mixed with Y-shaped hairs, is unique in the genus.

Stigmaphyllon is one of the wing-fruited genera of neotropical Malpighiaceae. The species are typically vines with long-petioled, elliptical to cordate leaves and bear clusters of yellow flowers arranged in compound inflorescences. In most the styles bear lateral appendages, the folioles, for which the genus is named. My monograph of Stigmaphyllon (Anderson, 1997a) includes 90 species, distributed in the West Indies and throughout Latin America from southern Mexico to northern Argentina, except in Chile. A recent collection from eastern Bahia, Brazil, proved to represent yet another species, which is described here.

Stigmaphyllon hispidum C. Anderson, sp. nov. TYPE: Brazil. Bahia: Mpio. Una, Fazenda Jureana, ramal com entrada no $\mathrm{Km} 18$ da Rodovia Una/São José da Vitória, Mata Higrófila Sul Baiana (Mata Atlântica), 22 July 1998, $L$. A. Mattos Silva et al. 3833 (holotype, CEPEC; isotype, MICH). Figure 1.

Liana, caulibus axibus petiolisque hispidis, indumento pilis simplicibus et pilis Y-formibus immixtis. Laminae 17.5-18 cm longae, 14-16 cm latae, late ovatae vel suborbiculares, supra velutinae, subtus tomentosae, margine sparsim glanduloso; petioli crassi, ca. $4.5 \mathrm{~mm}$ diametro. Inflorescentia thyrsiformis constata ex umbellis, floribus in quaque umbella 18-25(-30); pedunculi (7.5-)9-10.5 $\mathrm{mm}$ longi, pedicelli $4.5-8 \mathrm{~mm}$ longi. Petala lateralia limbo orbiculari, margine eroso-denticulato; petalum posticum limbo late elliptico, margine fimbriato-denticulato. Stamina heteromorpha, antheris pubescentibus; antherae sepalis antico-lateralibus oppositae 1-2 loculis reductis instructae, antherae sepalis postico-lateralibus oppositae steriles. Stylus anticus ca. $3.2 \mathrm{~mm}$ longus, utroque foliolo ca. $1.5 \mathrm{~mm}$ longo, ca. $1.2 \mathrm{~mm}$ lato, rectangulari; styli pos- tici ca. $4.5 \mathrm{~mm}$ longi, foliolo ca. $3 \mathrm{~mm}$ longo, ca. $2.5 \mathrm{~mm}$ lato, subquadrato. Samara ignota.

Vine. Stems and branches densely hispid, the hairs erect, mostly simple and basifixed, (0.5-)1$2.3 \mathrm{~mm}$ long, also with some Y-shaped hairs, the stalk $0.05-0.7 \mathrm{~mm}$ long, the arms $0.1-0.5 \mathrm{~mm}$ long and at an acute to right angle to each other, the second arm occasionally reduced to a spur. Leaves alternate?; laminas 17.5-18 cm long, 14-16 cm wide, broadly ovate to suborbicular, apex obtusemucronate, base truncate to shallowly cordate, adaxially velutinous, the hairs erect, mostly Yshaped, with the stalk $0.1-0.7 \mathrm{~mm}$ long and the arms $0.1-0.6 \mathrm{~mm}$ long, at an acute to right angle to each other, also with some simple basifixed hairs, 0.2-1.1 mm long, abaxially densely tomentose with T-shaped hairs (stalk 0.1-0.6 mm long, trabecula 0.6-1.3 mm long, straight or wavy); the midrib, primary, and secondary veins prominulous above and prominent below, and on both sides more densely pubescent than the laminar surface; laminar glands 0.2-0.3 mm diam., irregularly spaced, prominent or slightly raised, borne adjacent to the margin abaxially and hidden by the vesture; petioles 3-3.5 cm long, ca. $4.5 \mathrm{~mm}$ diam., densely hispid like the stems, not confluent across the node, with a pair of prominent but sessile glands at the apex, each gland $0.2-0.3 \mathrm{~mm}$ diam.; stipules not seen (obscured by the stem vesture?). Flowers 18 to 25 (to 30) per umbel, these borne in dichasia or small thyrses (axes to the 3rd order, hispid), the compound inflorescence axillary. Peduncles (7.5-)9$10.5 \mathrm{~mm}$ long, pedicels $4.5-8 \mathrm{~mm}$ long, terete, both densely pubescent with T-shaped hairs, peduncles (1.3-)1.4-2 times as long as the pedicels. Bracts and bracteoles $1.8-2 \mathrm{~mm}$ long, 0.8-1.2 mm wide, oblong to ovate, apex acute or obtuse, densely sericeous abaxially, eglandular. Sepals 2.8-3 mm long and wide, glands ca. $2 \mathrm{~mm}$ long, ca. $1 \mathrm{~mm}$ wide. All petals with the limb glabrous, yellow, limbs of lateral petals orbicular, margin erose-denticulate, the teeth up to $0.3 \mathrm{~mm}$ long; anterior-lateral petals: claw ca. $1.5 \mathrm{~mm}$ long, limb 11.5-12 $\mathrm{mm}$ long and wide; posterior-lateral petals: claw ca. 


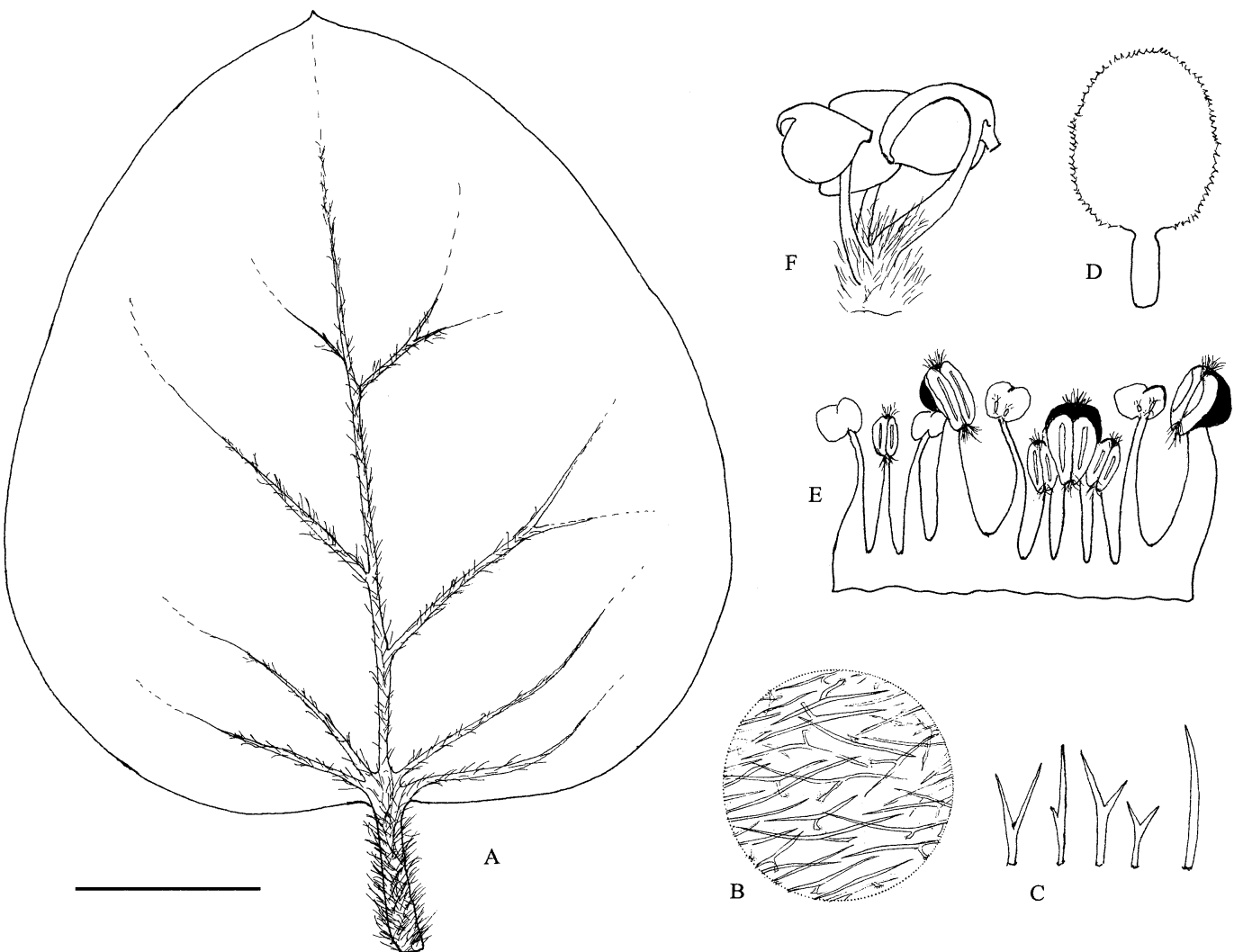

Figure 1. Stigmaphyllon hispidum C. Anderson. -A. Outline of leaf. -B. Detail showing abaxial laminar vesture. -C. Y-shaped hairs and a simple hair from the adaxial laminar vesture. - D. Posterior petal (the "flag"). -E. Androecium; stamen second from left opposes the posterior petal. -F. Gynoecium; anterior style at left. Scale bar: A $=4 \mathrm{~cm}, \mathrm{~B}=1.3 \mathrm{~mm}, \mathrm{C}=3 \mathrm{~mm}, \mathrm{D}=8 \mathrm{~mm}, \mathrm{E}, \mathrm{F}=4 \mathrm{~mm}$.

$1 \mathrm{~mm}$ long, limb ca. $10.5-11 \mathrm{~mm}$ long and wide; posterior petal: claw ca. $3.5 \mathrm{~mm}$ long, indented at apex, limb ca. $8.5 \mathrm{~mm}$ long, ca. $7 \mathrm{~mm}$ wide, broadly elliptical, margin fimbriate-denticulate, the fimbriae/teeth up to $0.3 \mathrm{~mm}$ long. Stamens unequal, those opposite the posterior-lateral petals (and the posterior styles) the largest, those opposite the anteriorlateral sepals with the filaments subequally long, anthers of those opposite the lateral sepals with the connective enlarged, those opposite the anteriorlateral sepals with 1 or 2 unequal reduced locules, those opposite the posterior-lateral sepals eloculate; loculate anthers pubescent. Stamen opposite anterior sepal: filament ca. $2.8 \mathrm{~mm}$ long, anther ca. 1.2 mm long; stamens opposite anterior-lateral petals: filaments ca. $1.8 \mathrm{~mm}$ long, anthers ca. $1 \mathrm{~mm}$ long; stamens opposite anterior-lateral sepals: filaments ca. $3.8 \mathrm{~mm}$ long, connectives ca. $1 \mathrm{~mm}$ long, locules $0.1-0.3 \mathrm{~mm}$ long; stamens opposite posteriorlateral petals: filaments ca. $3.8 \mathrm{~mm}$ long, anthers ca. 1.4 mm long; stamens opposite posterior-lateral sepals: filaments ca. $2.8 \mathrm{~mm}$ long, connectives ca.
$1 \mathrm{~mm}$ long, locules absent; stamen opposite posterior petal always shorter than the adjacent two: filament ca. $2.5 \mathrm{~mm}$ long, anther ca. $1 \mathrm{~mm}$ long. Anterior style ca. $3.2 \mathrm{~mm}$ long, shorter than the posterior two, terete, glabrous, erect or slightly incurved; each foliole ca. $1.5 \mathrm{~mm}$ long, ca. $1.2 \mathrm{~mm}$ wide, rectangular. Posterior styles ca. $4.5 \mathrm{~mm}$ long, terete, the proximal $2 / 3-3 / 4$ with scattered hairs adaxially, lyrate; foliole ca. $3 \mathrm{~mm}$ long, ca. $2.5 \mathrm{~mm}$ wide, subsquare. Samara not seen.

This robust and showy species, known only from the type collection, was found in a remnant of native forest in a cocoa plantation. The common practice of retaining native trees to provide shade for Theobroma cacao has resulted in the patchy preservation of the native vegetation of coastal Bahia, which is rich in endemics.

Stigmaphyllon hispidum is easily recognized and readily distinguished from all other species of the genus by the densely hispid stems, axes, and unusually stout petioles. The vesture is composed of 
a unique mixture of Y-shaped hairs and of simple basifixed hairs (Fig. 1C); the latter are not found elsewhere in Stigmaphyllon, although they are known sporadically in other genera, e.g., Pterandra hirsuta C. Anderson (Anderson, 1997b). At least in $S$. hispidum, the simple hairs may result from the loss of one arm in a Y-shaped hair. The arms of the Y-shaped hairs are often unequally long; sometimes the second arm is reduced to a mere spur. In $S$. hispidum the laminas are abaxially tomentose, the hairs T-shaped, but adaxially velutinous, again the vesture a mixture of Y-shaped and simple hairs.

An intriguing aspect of $S$. hispidum is the alternate arrangement of the leaves and the inflorescence axes; however, the two specimens I have seen consist of only a short portion of stem $(3 \mathrm{~cm}$, one node; $7 \mathrm{~cm}$, two nodes), each with one large compound inflorescence borne in one leaf axil. The shift from an opposite arrangement to an alternate one near and in the inflorescence occurs in other species of Stigmaphyllon (e.g., S. alternifolium Adr. Jussieu, S. cavernulosum C. Anderson) and other opposite-leaved vines. The only species with apparently truly alternate phyllotaxy is $S$. alternans Triana \& Planchon, of Amazonian Colombia, Ecuador, and Peru; perhaps future collections of $S$. hispidum will reveal that it is a second alternateleaved species.

Stigmaphyllon hispidum is most similar to $S$. gayanum Adr. Jussieu, endemic to the area of Rio de Janeiro. Working $S$. hispidum through my key to the genus and the regional key (Anderson, 1997a), the reader would arrive at that species, which, of course, lacks the unique vesture of $S$. hispidum.
Both have adaxially velutinous laminas, and a similar androecium and gynoecium. Stigmaphyllon gayanum also differs in its smaller laminas (4.7$14 \mathrm{~cm}$ long), the basal glands often borne on the slim petiole (1-2 $\mathrm{mm}$ in diameter) well below the base of the lamina, and in its petals, all with fimbriae up to $0.5 \mathrm{~mm}$ long. In $S$. hispidum the large laminas (17.5-18 cm long) are borne on stout petioles ca. $4.5 \mathrm{~mm}$ in diameter and bear a pair of prominent glands at the base of the lamina at the apex of the petiole. The margin of the posterior petal is fimbriate-denticulate and of the lateral petals erose-denticulate. The only other species with adaxially velutinous laminas is the Colombian $S$. velutinum Triana \& Planchon, which also has much smaller leaves than $S$. hispidum and all petals glandular-digitate-fimbriate. Stigmaphyllon velutinum also differs in details of the androecium and gynoecium. All anthers are glabrous and loculate; only those of stamens opposite the anterior-lateral sepals have reduced locules. The styles bear only a narrow lateral lip instead of folioles.

Acknowledgments. I thank André M. Amorim of CEPEC for calling my attention to the type collection and William R. Anderson for his helpful comments. For this study, I also consulted the rich collection of Malpighiaceae at MICH. Figure 1B was drawn by Karin Douthit.

\section{Literature Cited}

Anderson, C. 1997a. Monograph of Stigmaphyllon (Malpighiaceae). Syst. Bot. Monogr. 51: 1-313.

- 1997b. Revision of Pterandra (Malpighiaceae).

Contr. Univ. Michigan Herb. 21: 1-27. 